\title{
CORRECTION
}

Open Access

\section{Correction to: Intramural metastasis to the appendix from ascending colon cancer: a case report}

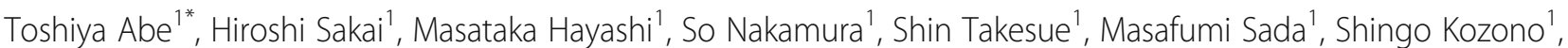
Yoshiki Kitaura', Yoshitaka Tanabe', Kazuyoshi Nishihara', Mari Mine², Sadafumi Tamiya² and Toru Nakano

\section{Correction to: Surgical Case Reports \\ https://doi.org/10.1186/s40792-020-00829-6}

In the original publication of this article [1], an author's name should be changed from Shin Takasue to Shin Takesue. The original article has been updated.

\section{Author details}

'Department of Surgery, Kitakyushu Municipal Medical Center, 2-1-1 Bashaku, Kokurakita-ku, Kitakyushu 802-0077, Japan. ${ }^{2}$ Department of

Pathology, Kitakyushu Municipal Medical Center, Kitakyushu, Japan.

Published online: 20 April 2020

\section{Reference}

1. Abe, et al. Surgical Case Reports. 2020;6:69

* Correspondence: t-abe@surg1.med.kyushu-u.ac.jp

${ }^{1}$ Department of Surgery, Kitakyushu Municipal Medical Center, 2-1-1

Bashaku, Kokurakita-ku, Kitakyushu 802-0077, Japan

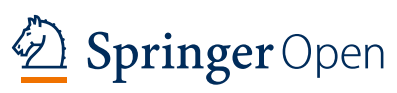

(c) The Author(s). 2020 Open Access This article is licensed under a Creative Commons Attribution 4.0 International License, which permits use, sharing, adaptation, distribution and reproduction in any medium or format, as long as you give appropriate credit to the original author(s) and the source, provide a link to the Creative Commons licence, and indicate if changes were made. The images or other third party material in this article are included in the article's Creative Commons licence, unless indicated otherwise in a credit line to the material. If material is not included in the article's Creative Commons licence and your intended use is not permitted by statutory regulation or exceeds the permitted use, you will need to obtain permission directly from the copyright holder. To view a copy of this licence, visit http://creativecommons.org/licenses/by/4.0/. 